J. Perinat. Med. 17 (1989) 221

\title{
A microcomputer data base system for maternal serum alpha fetopro- tein screening programmed in BASIC
}

\author{
Brooks A. Keel, Karen K. Durfee, and Sechin Cho \\ Department of Obstetrics and Gynecology, University of Kansas School of Me- \\ dicine-Wichita, The Women's Research Institute, Wichita, KS, USA
}

\section{Introduction}

Maternal serum alpha fetoprotein (MSAFP) screening is able to detect virtually all anencephalic fetuses, a majority of open spina bifida cases, and about one half of abdominal wall defects [1]. Recent evidence also suggests that MSAFP screening may also assist in the prenatal diagnosis of Down syndrome and other trisomy abnormalities $[2,8]$. These observations have resulted in a dramatic increase in the number of physician request for MSAFP measurements as well as an upsurge in the number of clinical laboratories performing this test. However, MSAFP screening involves much more than performing an assay and reporting a result. The clinical laboratory must not only provide an AFP result but also interpret the result, recommend appropriate action to be taken based on the result and provide a mechanism for appropriate follow-up, to document pregnancy outcome [6]. Moreover, due to the gestational age-dependent nature of AFP, and the reported effects of maternal status (such as age, weight and IDDM) on the result, the MSAFP laboratory report needs an interpretation and recommendation specifically tailored for each patient. This requires the clinical laboratory performing the MSAFP test to obtain and maintain an adequate data base on the patient being tested, integrate this data base with the AFP result, and provide the physician with a report based on this integration. In this paper we report on the development of a computer program which assists the MSAFP screening laboratory in meeting these criteria. This program, written in BASIC, 1) maintains a data base for patients tested, 2) allows input and storage of MSAFP results, 3) calculates the gestational age dependent result in multiples of the median (MOM), 4) makes an

\section{Curriculum vitae}

Brooks A. Keel, Ph.D., received his graduate education in Reproductive Endocrinology in the Department of Endocrinology at the Medical College of Georgia. He completed three years of post-doctoral training at the University of Texas Health Science Center in Houston and at the University of South

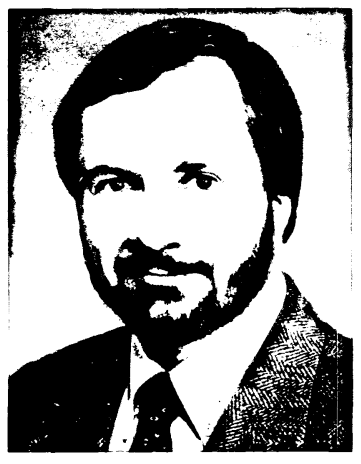
Dakota School of Medicine. He is currently an Associate Professor in Obstetrics and Gynecology at the University of Kansas School of Medicine-Wichita. Dr. Keel serves as Associate Director of the Reproductive Medicine Laboratories and Scientific Director of the Women's Research Institute. His research interests are in the area of the physiological role of and biochemical basis for glycoprotein charge microheterogeneity.

individualized interpretation of the result based on maternal age, weight and IDDM, 5) makes an appropriate recommendation for subsequent action based on the result, and 6) prints a report containing the above information. In addition, the program prints a daily log of patients tested, provides a follow-up sheet to assist in tracking abnormal results to term, updates the median values on different gestational ages at regular intervals, provides epidemiological data on positive and negative screening rates to be utilized as quality control measurements, and generates a monthly statement for billing purposes. The data base files are simple random access files which can be addressed 
for statistical manipulation and examination. The data files can also be easily intergrated into more powerful data base programs. The program can be easily modified by someone with minimal training in the BASIC programing language. To date this program has been successfully used in the analysis of over 6300 MSAFP samples.

\section{Description of the program}

\subsection{Hardware}

The computer used for this program is an IBM PC AT having 640K RAM, a color monitor, and IBM PC-DOS 3.1 operating system. The BASIC program and the patient data base files are stored in the hard disk drive. A standard double sided, double density $51 / / 4$ inch floppy diskette can hold approximately 3000 patients. The program was originally written for an IBM PC with $256 \mathrm{~K}$ RAM. However, it was later discovered that the on board memory was not sufficient to handle the monthly billing statement generating portion of the program.

\subsection{Software}

The MSAFP software was programmed in IBM BASIC A by the authors and consists of approximately 930 lines of programing (see Appendix). The patient data base information is stored in random access files with a record length of 113 characters per file. The following information is stored for each patient in the data file: patient name, age, weight, diabetes, doctor's name, doctor's billing code, date sample was drawn, whether sample is a repeat or first run, whether sample is serum or amniotic fluid, date sample was assayed, gestational age determined by last menstrual period (LMP), gestational age determined by ultrasound (USG), the AFP value, and the location of the refering physician or laboratory. Physicians are instructed to complete a requisition to provide the above information on each patient. This requisition along with the sample is delivered to the laboratory. Each sample presented to the laboratory for MSAFP testing is assigned the next available accession number (sample code). This code number correlates with the patients data base record number, and is used to access the patient's file.

The program is completely menu driven. From the main menu the user may choose one of eight options:
Input new patient data (2.2.1)

Input MSAFP results (2.2.2)

Print reports from stored data base (2.2.3)

Edit a stored file (2.2.4)

Print a patient $\log (2.2 .5)$

Print patient follow-up sheet (2.2.6)

Sort patients for billing (2.2.7)

Create data base files (2.2.8)

2.2.1 Input new patient data: Table I shows the screen for patient data base input and the information which can be entered. Most samples are not from insulin-dependent diabetic patients and are not repeats, so these values are set to default as a "no" answer (brackets). The report date is also defaulted to a date entered initially to save entry time. Once the patient data base information has been entered, the user has the option to store the information as entered, edit the information, or print a report. If a printed report is chosen, the gestational-age dependent MOM will be retrieved, the weight adjusted MOM calculated, an interpretation and recommendation chosen and the report will be generated (see below). The data base information is then stored in the random access file.

2.2.2 Input MSAFP results: It is often convenient to input the patient data base information into the computer before the actual MSAFP values are obtained. Patient information can then be logged onto the computer as soon as specimens arrive if this occurs prior to the time of the assay. The Input MSAFP Results option asks the user for the number of stored patients which require the addition of MSAFP value. The user is then prompted to enter the patients code number followed by the MSAFP value. Once this is completed, the program automatically recalls each patient's data base and inserts the MSAFP value. Thus, to enter a number of MSAFP values the user may use this option rather than recalling each data base individually and editing in the value.

2.2.3 Print reports from stored data base: This is the major calculation and data interpretation routine of the program. The user is first prompted for the number of reports needed, and is then asked to enter the sample code numbers in any order. The program then recalls the patients data base according to the sample code. The program then generates the report by first printing the patients name and other pertinent information contained in the data base (table II). If the maternal age and/or weight are not available, an asterisk 
Table I. Screen format for entering patient data base

MSAFP Patient Information

Name: ?

(Last, First)

Age: yrs.

Weight: lbs.

Diabetes: [no]

Sample Code:

AFP Value: $\mathrm{IU} / \mathrm{ml}$
Doctor/Code:

Draw Date://, Repeat Draw: [no]

Location: [Wichita]

Report Date: [10/25/88]

Gest Age LMP: wks, USG: wks

Table II. Example report form generated for a normal MSAFP result

\begin{tabular}{|c|c|c|}
\hline \multirow[t]{2}{*}{$\begin{array}{l}\text { Name: Doe, Jane } \\
\text { Age: 24, Weight: } 235 \text { lbs. } \\
\text { Draw Date: } 10 / 20 / 88 \\
\text { Diabetes: no } \\
\text { Repeat Draw: no }\end{array}$} & \multicolumn{2}{|l|}{$\begin{array}{l}\text { Doctor: Smith } \\
\text { Location: Wichita } \\
\text { Report Date: } 10 / 24 / 88 \\
\text { Dample: Serum } \\
\text { Sample Code: } 4000\end{array}$} \\
\hline & Last Menstrual Period & Ultrasound \\
\hline Gestational Age: & 22 weeks by LMP & 18 weeks by USG \\
\hline Assay Value: & $34.17 \mathrm{IU} / \mathrm{ml}$ & $34.17 \mathrm{IU} / \mathrm{ml}$ \\
\hline Multiple of Median: & $0.42 \mathrm{MOM}$ & $0.86 \mathrm{MOM}$ \\
\hline Weight Adjusted MOM: & $0.74 \mathrm{MOM}$ & $1.49 \mathrm{MOM}$ \\
\hline Normal Range: & $.42 \mathrm{MOM}$ to & \\
\hline
\end{tabular}

Interpretation: This serum AFP value, adjusted for maternal weight, is within the normal rnge for a 24 year old pregnant women at 18 weeks of gestation.

Recommendation: None.

Report Date:

Tech:

Sechin Cho, M.D.

Brooks A. Keel, Ph. D.

is printed in the respective locations on the report form and the physician is requested to provide the laboratory with this information (see below).

The next portion of the computer generated report concerns the calculation of the result (table II). The MSAFP assay value and gestational age are reported under a "Last Menstrual Period" and/or "Ultrasound" heading, depending upon the method(s) used for gestational age determination. The regressed assay multiple of the median (MOM) values for each gestational age between 14 and 25 weeks are written into the program as data statements (line 1620, Appendix). These values are read into the program internally (line 1640, Appendix) and the MOM for the recorded gestational age is determined and printed under the appropriate heading. The weight adjusted MOM is then calculated (lines 1650-1670, Appendix) by the formula [9]: Wt. Adj. MOM = MOM/(1.555 $-0.00417 \times$ Maternal Wt. in lbs.). The observed MOM and the weight adjusted MOM is then printed under the appropriate heading. The normal range for the individual patient is determined by the patients maternal age (low end) and the presence of insulin dependent diabetes. If the patient is $\leq 21$ years of age at the time of delivery, the low normal MOM is reported as $0.38 \mathrm{MOM}$. As the patient increases in age, this low normal value increases and is adjusted on the report accordingly. The actual values [8] are written into the program as data statements and are read internally (lines 1680-1690, Appendix). If the patient is reported as having insulin dependent dia- 
betes the upper normal limit is set at 2.0 MOM $[6,11]$ otherwise the upper normal limit is 2.5 MOM [4].

The final section interprets the MSAFP value and makes an appropriate recommendation. There are eight possible interpretation and recommendation subroutines. These are based on a normal result (table II), < 14 weeks of gestational age, abnormal low MSAFP (table III), abnormal high MSAFP (table IV), abnormal repeat MSAFP, and no interpretation possible due to lack of maternal age, weight or gestational age. Because of increased accuracy and reproducibility of USG determination of gestational age, USG information, if available, is used for the interpretation regardless of the LMP data. If only LMP data is available, this information is used for the interpretation. Also, because of the reported differences in MSAFP values due to excessive overweight or underweight and the accompanying differences in maternal blood volume [9], all interpretations are based on the weight adjusted MOM.

The actual interpretations used for a normal, abnormal low or elevated MSAFP are presented in tables II, III, and IV, respectively. If a repeat
MSAFP is also elevated, amniocentesis for amniotic fluid AFP and karyotype is recommended. For abnormal low MSAFP results, the actual risk for Down syndrome for that patient is determined from a Down syndrome odds table [8] based on the patient's age and the MOM value and is handwritten on the report form (table III). In addition, because the risk for fetal abnormality is significantly great for women 35 years of age or older, amniocentesis to rule out chromosomal abnormalities is recommended for patients 35 years or older at the time of delivery even if the MSAFP result is normal [3]. The end of the report form provides space for the technician's initials and for the laboratory director/geneticist signature and date. Report forms are printed on continuous-feed forms to allow unassisted operation in printing.

2.2.4 Edit a stored file. This option allows the user to edit any portion of the patient's data base already stored. This option is especially useful if additional information, such as USG gestational age, maternal weight or age, becomes available after the initial reports are printed. Once the file is edited, the user may store the edited data base or request an updated report to be printed.

Table III. Example MSAFP report form for an abnormally low MSAFP illustrating the results, interpretation and recommendation sections of the report

Last Menstrual Period Only

Gestational Age:

Assay Value:

Multiple of Median:

Weight Adjusted MOM:

Normal Range:
17 weeks by LMP

$15.42 \mathrm{IU} / \mathrm{ml}$

$0.48 \mathrm{MOM}$

$0.52 \mathrm{MOM}$

$.81 \mathrm{MOM}$ to $2.5 \mathrm{MOM}$

Interpretation:

The serum AFP value, adjusted for maternal weight, is low for a 35 year old pregnant women at 17 weeks of gestation.

The risk of Down Syndrome in this pregnancy is greater than $1 / 270$. Actual calculated risk for this patient is $1 /$

Recommendation: 1. An ultrasound study is indicated, if not done already, to rule out:
a. overestimated gestational age
b. missed abortion
c. molar pregnancy or non pregnancy

2. If gestational age is correct, amniocentesis is indicated to rule out Down Syndrome and other chromosomal abnormalities.

Report Date:

Tech:

Sechin Cho, M. D.

Brooks A. Keel, Ph. D. 
Table IV. Example MSAFP report for an abnormally elevated MSAFP illustrating the results, interpretation and recommendation sections

\author{
Ultrasound Only \\ 18 weeks by USG \\ $368.16 \mathrm{IU} / \mathrm{ml}$ \\ $9.88 \mathrm{MOM}$ \\ 10.39 MOM \\ $.51 \mathrm{NOM}$ to $2.5 \mathrm{MOM}$
}

Gestational Age:

Assay Value:

Multiple of Median:

Weight Adjusted MOM:

Normal Range:

Interpretation:

This serum value, adjusted for maternal weight, is elevated for a singleton pregnancy at 18 weeks of gestation.

Recommendation: Repeat MSAFP is recommended immediately along with complete sonogram, if not done already, to rule out:

a. underestimated gestational age

b. multiple pregnancy

c. fetal demise or anomalies

Report Date:

Tech:

Sechin Cho, M. D.

Brooks A. Keel, Ph. D.

2.2.5 Print a patient log: This option allows the user to print a log of the patients assayed each day. The user is asked to enter the first and last sample codes to be logged. The program then recalls each data base and prints the code number, patient name, doctor's name, doctor's billing code, and the draw date of each sample. This function is particularly useful for generating a daily laboratory $\log$ of patient samples assayed, which is required by many state and federal laboratory licensing agencies. This $\log$ is also helpful in tracking patient samples on a day to day basis.

2.2.6 Print patient follow-up sheet: Accurate and comprehensive follow-up of patients who have abnormal MSAFP results is mandatory for a MSAFP screening program [5]. This option asks the user for the sample code of the abnormal result. The program then recalls and prints an abbreviated report for this patient (table V). This printed follow-up sheet contains space for input of the results of ultrasound, repeat draw MSAFP, amniocentesis, acetylcholinesterase assay, and results of delivery. This follow-up sheet can then be filed and the record of this patient's progress maintained until the final outcome is known. This information is extremely important in determining the laboratories false positive and false negative predictive rates based on the MSAFP result and pregnancy outcome.
2.2.7 Sort patients for billing: This option generates monthly billing statements. The user is asked for the first and last sample code for those samples run during the preceding month. The program then recalls each patient's data base and sorts the patients according to the doctor's billing code subgroup, which is arbitrarily assigned by the user. The physicians within each subgroup are then arranged alphabetically according to the physician's last name. Once accomplished, the program prints the patient name, doctor name, draw date and sample code for each billing code. This option generates an individual billing statement for each physician, laboratory or clinic and provides not only a financial statement but a permanent record of patients assayed for each patient referring group.

2.2.8 Create data base files: This option converts the random access patient data file into data files which can be intergrated into other more powerful data base programs. The user is asked to enter the first and last patient code number to convert. The program then converts the random access file into an individual sequential file specific for each variable contained in the patient data base (patient name, age, weight, assay value, etc.). The converted sequential files are then stored onto a floppy disk. The data can then be easily imported into other commercially available data base programs, such as Lotus $123^{\mathrm{R}}$ or dBase $\mathrm{III}^{\mathrm{R}}$. 
Table V. Example patient follow-up sheet

Name: Doe, Jane

Age: 31 Weight: $145 \mathrm{lbs}$.

Draw Date: $05 / 18 / 87$

Diabetes: No

Repeat Draw: No

Gest. Age: 0 wks by LMP

Assay Value: $368.16 \mathrm{IU} / \mathrm{ml}$
Doctor: Smith

Location: $N / A$

Report Date: 05/19/87

Sample: Serum

Sample Code: 58

18 wks by USG

$M O M=9.78$, Wt Corr $M O M=10.29$

Follow-Up

A. Ultrasound Date:

1. Declined by Pt.:

2. wks by USG

3. Overestimate: MOM Wt Corr MOM

4. Underestimate: MOM Wt Corr MOM

5. Concurrent:

6. Abnormal:

Findings:
C. Amniocentesis Date:

1. Declined by Pt.:

2. Ultrasound: wks by USG Findings:

3. AFAFP: $\mathrm{IU} / \mathrm{ml}$, MOM

4. Karyotype:
B. Repeat Draw Date:

1. Declined by Pt.: wks LMP wks USG

2. Normal: MOM W W Corr MOM

3. Abnormal:

MOM Wt Corr MOM

D. Acetylcholinesterase Date:

Findings:

E. Follow-Up Ultrasound Date:

Findings:

Findings:
F. Infant Normal: DOB:

SGA: AGA: LGA: G. A.: RDS: wks. Birth Wt: lbs. Abnormal Findings:

\section{Comment}

The program described herein is extremely easy to use yet powerful enough to address most of the needs of a MSAFP screening program. The concept behind the program satisfies the requirements for a MSAFP laboratory by 1) providing an easily accessible patient data base, 2) reporting a result and providing an interpretation of the result and recommendation for the individual patient, and 3) allowing for patient follow-up. By writing the program in the BASIC language, it can be easily modified to suit individual needs by anyone with a minimal amount of programing experience. The random access patient data base files can be readily addressed by other BASIC programs and allows for statistical manipulation of the data. The 
Create Data Base Files option allows the patient data base information to be incorporated into other commercially available, more powerful data base programs. We have found the report format to be very advantageous and convenient for physicians. By tailoring the report for the individual patient, the physician is able to rapidly assimilate the information without having to compare the observed result with a list of normal values for the respective gestational age. When both the LMP and USG gestational age data are available, we report the results for both ages. Although our interpretation and recommendation are based on USG data when available, we felt it important to provide the physician with both sets of data. When only LMP data are available, our interpretation and recommendations are based on these data, allowing the physician to take responsibility for accuracy of gestational age estimates.

Other commercially available data base software systems are available and have been implemented for MSAFP screening programs [7] and in vitro fertilization programs [10]. We have chosen to create our own program to maintain maximum flexibility and to allow for incorporation of interpretation and recommendation formulas. We have found this program to be easy to use and to modify as future needs become apparent. By combining this program with other data base programs the data can also be utilized for other statistical purposes.

\begin{abstract}
A computer program was developed for the IBM PC computer to be used for maternal serum alpha fetoprotein screening (MSAFP). This program, written in BASIC, 1) maintains a data base for patients tested, 2) allows input and storage of MSAFP results, 3) calculates the gestational age dependent result in multiple of the median (MOM), 4) makes an individualized interpretation of the result based on maternal age, weight and diabetes, 5) makes an appropriate recommendation for subsequent action based on the result, and 6) prints a
\end{abstract}

report containing the above information. In addition, the program will print a daily $\log$ of patients tested, provides a follow-up sheet to assist in tracking abnormal results to term, converts the data files into files which can be easily intergrated into more powerful data base programs, and generates a monthly statement for billing purposes. The program can be easily modified by someone with minimal training in the BASIC programing language.

Keywords: AFP, alpha fetoprotein, database, maternal serum alpha fetoprotein, microcomputer, prenatal diagnosis.

\section{Zusammenfassung}

Screening maternaler Serum-Alpha-Fetoproteinwerte unter Verwendung eines in BASIC programmierten Mikrocomputers

Grundsätzlich können alle anenzephalen Feten, die Mehrheit der Fälle mit offener Spina bifida sowie etwa die Hälfte aller Bauchwanddefekte über ein Screening der Alpha-Fetoproteinwerte im mütterlichen Serum (MSAFP) aufgedeckt werden. Darüberhinaus zeigen neuere Erkenntnisse, daß ein MSAFP-Screening auch bei der pränatalen Diagnose eines Down-Syndroms und anderer Trisomien von Bedeutung ist. Dies führte zu einem dramatischen Anstieg der Anforderungen von MSAFP-Messungen seitens der Ärzte sowie einer enormen Zunahme der klinischen Labore, die diese Messungen durchführen. Jedoch beinhaltet ein MSAFP-Screening mehr als die Durchführung des Tests und Wiedergabe des Ergebnisses. Das Labor muß nicht nur den AFP-Wert liefern, sondern ihn auch interpretieren sowie Konsequenzen des Ergebnisses empfehlen. Das betrifft Kontrolluntersuchungen sowie letztlich Entscheidungen über den weitern Schwangerschaftsverlauf. Außerdem muß berücksichtigt werden, daß das AFP vom Gestationsalter abhängt und maternale Parameter wie Alter, Gewicht und z. B. ein insulinpflichtiger Diabetes mellitus (IDDM) einen Einfluß auf das Ergebnis haben. D.h., daß das MSAFP-Labor eine auf jede Patientin spezifisch zugeschnittene Interpretation und Empfehlung liefern muß. Das Labor braucht daher die adäquaten Daten von jedem zu testenden Patienten und muß auf deren Hintergrund den AFP-Wert analysieren, um dem Arzt ein aussagekräftiges Ergebnis zu liefern. In der vorliegenden Arbeit berichten wir über die Entwicklung eines Computer-Programms, das das MSAFP-Screening-Labor bei diesen Aufgaben unterstützt. Dieses in BASIC aufgezeichnete Programm speichert erstens die Daten für jeden getesteten Patienten, speichert zweitens alle MSAFP-Ergebnisse, berechnet drittens den Wert in Abhängigkeit vom Schwangerschaftsalter unter Berücksichtigung vieler Medianwerte (MOM), erlaubt viertens eine individuelle Interpretation im Hinblick auf mütterliches Alter, Gewicht und Vorhandensein eines IDDM, gibt fünftens adäquate Empfehlungen für das weitere Vor- 
gehen und druckt zuletzt einen Bericht aus, der alle o.g. Informationen enthält. Darüberhinaus kann das Programm ein Tagesprotokoll von jedem getesteten Patienten ausdrucken und somit eine Hilfe bei der Weiterverfolgung suspekter Werte bis hin zum Termin sein. Ebenso können die Medianwerte unterschiedlicher Schwangerschaftsalter in regelmäßigen Abständen korrigiert werden. Es stehen epidemiologische Daten bezüglich positiver und negativer Screening-Raten zur Verfügung, die als Qualitätskontrollen benutzt werden können, und mo- natlich können Rechnungsaufstellungen gemacht werden. Die Datenstreifen sind einfach zu handhaben und können für statistische Manipulationen und Tests leicht benutzt werden. Sie können problemlos in größere Programme integriert werden. Minimale Kenntnisse der Programmiersprache BASIC reichen aus, um das Programm zu modifizieren. Bislang wurde das Programm bei der Analyse von über 6300 MSAFP-Proben erfolgreich eingesetzt.

Schlüsselwörter: AFP, Alpha-Fetoprotein, AFP im maternalen Serum, Datenspeicherung, Mikrocomputer, pränatale Diagnose.

\section{Résumé}

Système de données par micro ordinateur pour l'étude de l'alpha feto protéine sérique maternelle

Le dosage systématique de l'alphafœtoprotéine sérique maternelle (MSAFP) permet de dépister virtuellement la totalité des fœtus anencéphales, une majorité des cas de spina bifida ouverts, et environ la moitié des défects de la poraoi abdominale. Des données résentes suggèrent également que le dosge systématique de MSAFP peut aider au diagnostic prénatal de la trisomie 21 et des autres trisomies. Ces observation ont entraîné une élévation importante du nombre de praticiens nécessaires pour les dosages de MSAFP ainsi qu'une augmentation majeure du nombre du nombre de laboratoires réalisant cet examen.

Cependant, le dépistage per MSAFP implique beaucoup plus d'éléments que la simple réalisation d'un dosage et la transmission d'un résultat.

Le laboratoire clinique ne doit pas seulement fournir des résultats d'AFP mais également interpréter ces résultats, recommander une attitude appropriée fondée sur ces résultats et assurer un système du suivi approprié, comportant l'issue de la grossesse. De plus, le résultat d'MSAFP du Laboratoire nécessite une interprétation et des recommendations spécifiquement sur mesures pour chaque patient du fait de la nature de AFP dépendante de l'âge gestionnel, et des effets signalés du status maternel (âge, poids, diabète insulino-dépendant) sur les résultats. Tout celà nécessite que le laboratoire clinique qui réalise le test MSAFP obtienne et conserve une base de données adéquates concernant le patient à tester, qu'il intègre ces données aux résultats d'AFP et qu'il fournisse au clinicien un rapport fondé sur cette intégration. Dans cet article nous rapportons le développement d'un programme d'ordinateur qui assiste le dépistage en laboratoire de la MSAFP en réunissant ces cirtères. Ce programme, écrit en basic:

1) garde une base de données sur les patients testés

2) permet l'entrée et le stockage des résultats de MSAFP

3) calcule les résultats dépendants de l'âge gestationnel en multiples de la moyenne (MOM)

4) fournit une interprétation individuelle des résultats en fonction de l'âge maternel, du poids et du diabète insulino-dépendant

5) procure des recommandations appropriées pour une stratégie fondée sur ces résultats

6) imprime un rapport contenant les informations cidessus.

En outre, le programme peut imprimer un journal quotidien des patients testés, fournir une feuille de suivi pour aider au dépistage des résultats anormaux à terme, met à jour les valeurs moyennes aux différents âges gestationnels à intervalles réguliers, fournit des données épidémiologiques sur les taux de faux positifs et de faux négatifs que l'on peut utilisier comme controles de qualité, et il fournit pour la facturation un relevé mensuel. Les disquettes de base de données sont simples et peuvent être fournies pour des travaux statistiques.

Ces disquettes de données peuvent également être intégrées aisément dans des programmes de base de données plus puissantes.

Le programme peut aisément être modifié par quelqu'un qui possède un minimum d'entraînement en basic.

A ce jour, ce programme a été utilisé avec succès pour l'analyse de plus de 6300 échantilles de MSAFP.

Mots-clés: AFP, alpha fœto protéine, alphafœtoprotéine sérique maternelle, base de données, micro-ordinateur, diagnostic prénatal.

\section{References}

[1] BOPPORT I et al: Maternal serum alpha-fetoprotein screening for neural tube defects. Prenatal Diag 5 (1985) 77

[2] CuCKLe HS, NJ Wald, RH Lindenbaum: Maternal serum alpha-fetoprotein measurement: a screening test for Down syndrome. Lancet 1 (1984) 926
[3] Dimaio MS, A Baumgarten, RM Greenstein, HM SAAL, MJ MAHONEY: Screening for fetal Down's syndrome in pregnancy by measureing maternal serum alpha-fetoprotein levels. N Engl J Med 317 (1987) 342 
[4] Doran TA et al: Maternal serum fetoprotein screening: report of a Canadian pilot project. CMAJ 137 (1987) 285

[5] Milunsky A, E Alpert, J Kitzmiller, M YouNGER, R NEFF: The importance of alpha-fetoprotein screening in diabetic pregnant women. Am J Obstet Gynecol 142 (1982) 1030

[6] MizeJewski GJ: Alpha fetoprotein testing: regulatory and technical considerations. Lab Manag April (1987)

[7] O'BRIEN WF, R HiCkMAN: A database system for alpha fetoprotein screening. J Perinat Med 15 (1987) 95

[8] Palomaki GE, JE Haddow: Maternal serum fetoprotein, age, and Down syndrome risk. Am J Obstet Gynecol 156 (1986) 460

[9] Palomaki GE, GJ Knight, EM Kloza, JE HadDow: Maternal weight adjustment and low serum fetoprotein values. Lancet 1 (1985) 468
[10] Riss PA, A Reinthaller: A simple database system for an in-vitro fertilization programme using commercial software. Br J Obstet Gynecol 93 (1986) 999-1001

[11] Wald NJ, HS Cuckle, J Boreham, G Stirrat, A TURNBULL: Maternal serum alpha-fetoprotein and diabetes mellitus. Br J Obstet Gynecol 86 (1979) $101-105$

Remark: Appendix may be obtained directly from the author.

Brooks A. Keel, Ph. D.

Scientific Director

The Women's Research Institute 2903 E. Central

Wichita, KS 67214

U.S. A. 